\title{
Adaptations of Mammary Uptake and Nutrient Use to Once-Daily Milking and Feed Restriction in Dairy Cows
}

\author{
J. Guinard-Flament, ${ }^{1}$ E. Delamaire, P. Lamberton, and J. L. Peyraud
}

INRA, Agrocampus Rennes, UMR1080, Dairy Production, F-35590 St Gilles, France

\begin{abstract}
The aim of this study was to gain a clearer understanding of the different levels of regulation involved in the reduction in milk yield in response to once-daily milking and feed restriction. The treatments were designed as a $2 \times 2$ factorial arrangement of 2 milking frequencies (once- or twice-daily milking) and 2 feeding levels (70 or $98 \%$ of requirements determined $1 \mathrm{wk}$ before the trial). The cows were surgically prepared to study the net mammary balance of the nutrients that are precursors of milk components. Mammary efficiency in synthesizing milk components was estimated using a milk output:mammary uptake ratio. No interaction was observed between the effects of milking frequency and feeding level on milk and blood parameters except for milk protein yield, milk fatty acid profile, and nonesterified fatty acids metabolism. Once-daily milking and feed restriction reduced milk yield by 5.1 and $2.9 \mathrm{~kg} / \mathrm{d}$ and fat-corrected milk yield by 4.2 and 4.1 $\mathrm{kg} / \mathrm{d}$, respectively. Both treatments induced a decrease in mammary blood flow. Once-daily milking led to a reduction in the extraction rate of glucose but no changes to the lactose output:glucose uptake ratio. Feed restriction did not change the glucose extraction rate but tended to improve the lactose output:glucose uptake ratio. Under once-daily milking, the slight increase in milk fat content ( 0.34 percentage units) was linked to a depressed uptake of glucose and acetate but without any variations in the uptake of $\beta$-hydroxybutyrate and total glycerol and in the efficiency of acetate and $\beta$ hydroxybutyrate conversion to short- and mediumchain fatty acids in milk. The decline in milk fat and protein contents $(-0.43$ and -0.23 percentage units, respectively) under feed restriction was associated with relatively similar reductions in the mammary uptake of all nutrients and with enhanced conversion of the glucose taken up by the mammary gland and used for lactose synthesis. As a result, once-daily milking and
\end{abstract}

Received April 5, 2007.

Accepted August 3, 2007.

${ }^{1}$ Corresponding author: Jocelyne.Flament@agrocampus-rennes.fr feed restriction seem to affect milk yield through mechanisms that may be different and relatively independent.

Key words: dairy cow, once-daily milking, feed restriction, mammary uptake

\section{INTRODUCTION}

In the dairy cow, once-daily milking (ODM) and feed restriction markedly reduce milk yield and generate a series of modifications to milk composition. Switching to ODM for short periods ( 1 to $12 \mathrm{wk}$ ) reduces milk yield by 20 to $30 \%$ and is almost always accompanied by an increase in milk fat content and a smaller increase in protein content (Davis et al., 1999; Rémond and Pomiès, 2005). A 20 to $40 \%$ reduction in ingested DM can reduce milk yield by 15 to $25 \%$; this may or may not affect the milk fat content, and changes to protein contents may range from -0.07 to $+0.06 \%$ (Johnson, 1984; Vicini et al., 1988; Friggens et al., 1998). Furthermore, recent studies have shown that the effects of reducing milking frequency and feed intake are additive with respect to milk volume (Lacy-Hulbert et al., 1999; Rémond et al., 2002, 2005). Therefore, reducing the feed intake of cows switched to ODM leads to a much more important drop in milk yield.

The reduction in milk yield caused by these 2 factors could be associated with different and nutrient-dependent adaptations of the mammary metabolic activity. Indeed, both of these treatments decreased milk yield but induced different variations in milk composition. Moreover, the signals that trigger modifications to milk yield and composition are different between ODM and feed restriction. Under ODM, inhibition of milk production results from a local control, linked to the milk accumulating in the udder between milkings (Davis et al., 1999). Regarding feed restriction, a reduction in the amount of absorbed nutrients is associated with metabolic adaptations altering milk production. To our knowledge, no study has yet been performed that combines these 2 factors to determine their effects on the arterial availability of nutrients in the udder, the efficiency of their mammary extraction, and the efficiency of their conversion into milk components. The aim of 
the present study was to understand how these 2 treatments, in combination or applied separately, might reduce milk yield. Special attention was given to glucose because it is the principal precursor of lactose, the major osmotic agent in milk. In addition to the additive effects of ODM and feed restriction on milk yield, this paper will discuss the loss of milk yield in terms of glucose utilization by the mammary gland and concomitant variations in milk composition in terms of nutrient utilization.

\section{MATERIALS AND METHODS}

\section{Treatments, Cows, and Experimental Design}

The treatments were designed as a $2 \times 2$ factorial arrangement of 2 milking frequencies and 2 feeding levels. Cows were milked twice (twice-daily milking, TDM, 12-h milking interval) or ODM (24-h milking interval) and fed to meet either 98 or $70 \%$ of requirements of cows when milked twice daily. The $98 \%$ feeding level treatment was chosen to avoid feed refusals while still meeting requirements of cows milked twice daily. The 70\% feeding level was chosen assuming that the requirements of cows switched to ODM would be reduced by about $30 \%$ because of the reduction in milk yield. The quantity of DM given was calculated from the requirement values determined during the week before the start of the experiment, when cows were fed ad libitum.

Five multiparous Holstein cows $(657 \pm 67 \mathrm{~kg}$ of BW), in their third or fourth lactation and at $162 \pm 20$ DIM at the beginning of the experiment, were used. The cows were prepared surgically to estimate the mammary metabolism of nutrients in the right-half udder of each cow, according to the methods described by Guinard et al. (1994). One month before the beginning of the experiment, 2 permanent catheters (polyurethane catheter tubing, i.d. of $1.0 \mathrm{~mm}$, o.d. of $1.7 \mathrm{~mm}$; Uno, Roestvaststaal B.V., Zevenaar, the Netherlands) were inserted into the right carotid artery and subcutaneous abdominal vein to measure arterio-venous differences (AVD) in nutrient concentrations. The arterial and venous catheters were protected by silastic tubing (Silclear medical-grade silicone tubing, i.d. of $1.57 \mathrm{~mm}$, o.d. of $3.18 \mathrm{~mm}$; VWR International SAS, Briare, France). A Dacron ring (Mersutures, TS53, Ethicon, Issy-LesMoulineaux, France) was fixed around the catheters as they left the body to prevent infection. An ultrasonic flow probe (Probe $20 \mathrm{~S}$, i.d. of $20 \mathrm{~mm}$, cable length of 2.5 $\mathrm{m}$; Transonic Systems Inc., Ithaca, NY) was implanted around the right external pudic artery before the Sshaped bend in the artery, to measure mammary blood flow (MBF). The flow probe cable was also protected with silastic tubing (Silclear medical-grade silicone tub-
Table 1. Chemical composition and nutritive value of feedstuffs (based on DM content)

\begin{tabular}{lccc}
\hline Item & $\begin{array}{c}\text { Corn } \\
\text { silage }\end{array}$ & $\begin{array}{c}\text { Energy } \\
\text { concentrate }^{1}\end{array}$ & $\begin{array}{c}\text { Soybean } \\
\text { meal }\end{array}$ \\
\hline $\mathrm{OM}, \%$ & 95.8 & 93.6 & 93.5 \\
$\mathrm{CP}, \%$ & 5.8 & 17.7 & 48.7 \\
Cellulose, \% & 23.3 & 9.3 & 57 \\
NDF, \% & 47.9 & 27.8 & 16.7 \\
$\mathrm{ADF}, \%$ & 26.2 & 11.5 & 87 \\
$\mathrm{NE}_{\mathrm{L}}, \mathrm{Mcal} / \mathrm{kg}$ & 1.53 & 1.68 & 2.04 \\
$\mathrm{PDIE}^{2}$ g/kg & 68 & 119 & 248 \\
\hline
\end{tabular}

${ }^{1} 21.5 \%$ wheat, $22 \%$ barley, $20 \%$ beet pulp, $17 \%$ fine wheat bran, $15 \%$ rapeseed meal, $2 \%$ cane molasses, $0.5 \%$ calcium carbonate, $1 \%$ salt, $1 \%$ sodium bicarbonate (on DM basis).

${ }^{2}$ Protein truly digested in the small intestine delimited by energy supply (Jarrige, 1989).

ing, i.d. of $3 \mathrm{~mm}$, o.d. of $6 \mathrm{~mm}$, VWR International SAS). Two rings of Dacron (Mersutures, TS53, Ethicon) were placed along the cable and at the level of exteriorization to prevent any spread of infection.

The experiment was divided into 2 principal 3-wk periods during which cows were fed either 98 or $70 \%$ of their requirements during the first period and the reverse during the second period. The first week of each period was for adaptation to feeding level where cows were all milked twice daily (0630 and $1830 \mathrm{~h}$ ). During the second week, cows were milked either once or twice daily (ODM or TDM), and during the third week, the milking frequency was reversed. One cow was withdrawn from the study during the last week of the second period because of a catheter dysfunction. No mastitis was observed during this experiment $(\mathrm{SCC}=147 \pm 306$ $\times 10^{3}$ cells $/ \mathrm{mL}$ ).

\section{Feeding}

The ration provided $1.6 \mathrm{Mcal}$ of $\mathrm{NE}_{\mathrm{L}}$ and $97 \mathrm{~g}$ of protein truly digested in the small intestine (PDI) per $\mathrm{kg}$ of DM (Jarrige, 1989). The diet consisted of $70 \%$ corn silage, $14.5 \%$ energy concentrate, $14 \%$ soybean meal, and $1.5 \%$ minerals and vitamins (Table 1 ). The cows were fed twice daily and had access to food for $8 \mathrm{~h}$ after each allocation (from 0715 to $1515 \mathrm{~h}$ and from 1900 to $0300 \mathrm{~h}$ ). The DM content of corn silage was determined daily to adjust the quantities offered. When feed was refused, the quantities were weighed.

\section{Measurements, Sampling, and Analyses}

MBF. The MBF was monitored continuously throughout the study. The sampling rate of flowmeters (T208D, Transonic Systems Inc.) was fixed at $200 \mathrm{~Hz}$. The MBF was averaged every minute and recorded using IOX software (Emka Technologies, Paris, France). 
The cows were also fitted with a sensor to record their position (standing or lying). Because the MBF varies according to the animal's position, $\mathrm{MBF}$ and positions were recorded simultaneously to study variations in the MBF as a function of the cow's position.

Blood. Blood samples were collected to determine any variations in the plasma nutrient concentration (the precursors of milk components) simultaneously in the artery and vein using heparinized syringes (S-Monovette, $7.5 \mathrm{~mL}$, Sarstedt, Nümbrecht, Germany). Blood samples were collected on the last day of each experimental week at 1.5 -h intervals over a 24 -h period, the first sample being taken $0.5 \mathrm{~h}$ after morning milking. The cows were standing up during blood sampling. Blood samples were kept on ice and centrifuged at 2,500 $\times g$ for $10 \mathrm{~min}$ at $4^{\circ} \mathrm{C}$. Plasma samples were pooled per cow and per experimental week and assayed using colorimetric enzymatic reactions with a multiparameter analyzer (Kone Instruments Corporation, Espoo, Finland). To analyze the mammary metabolism of milk precursors, the concentrations of glucose (precursor of lactose), $\alpha$-amino $\mathrm{N}$ (precursor of milk proteins), and acetate, BHBA, NEFA, and total glycerol (milk fat precursors) were determined in arterial and venous plasma, as described by Delamaire and Guinard-Flament $(2006 a, b)$. To estimate mammary oxidative metabolism, dioxygen and carbon dioxide concentrations were determined by a gas analyzer (ABL 625, Radiometer Copenhagen, Brønshøj, Denmark) from blood samples collected in special blood gas heparinized syringes (S-Monovette, $2 \mathrm{~mL}$, Sarstedt). Plasma insulin and IGFI concentrations were determined from plasma samples collected in EDTA syringes (S-Monovette EDTA $\mathrm{K}_{2}$-Gel, $7.5 \mathrm{~mL}$ ) and analyzed as described by Lemosquet et al. (1997) and Abribat et al. (1990), respectively. The intraassay coefficient of variation of plasma controls was $6.6 \%$ for insulin (1 assay for the entire experiment) and 3.91 for IGF-I, and the interassay coefficient of variation was 1.81 for IGF-I.

Milk. During each experimental week, each half-udder was milked separately to align the results with AVD measurements. Milk yield was recorded at each milking, and the fat and protein contents were determined by infrared analysis (Milkoscan, Foss Electric, Hillerød, Denmark). On the last day of each experimental week, milk samples were collected during each milking from the right-half udder. Milk samples from cows milked twice-daily were pooled and balanced against the milk yield of each milking to obtain a daily representative milk sample. The milk was analyzed for lactose with a colorimetric enzymatic reaction (kit for lactose/ D-galactose, Roche, Meylan, France) using a multiparameter analyzer (Kone Instruments Corporation). The milk was analyzed for total $\mathrm{N}$ using the Kjeldahl proce- dure, and for casein (precipitation at $\mathrm{pH} 4.6$ with $10 \%$ acetic acid and $1 M$ sodium acetate). Milk fatty acids were analyzed to determine the percentages of short-, medium-, and long-chain fatty acids, according to the method described by Couvreur et al. (2007), based on the method developed by Bauchard and Duboisset (1983). Briefly, milk fatty acids were transesterified with $1 \mathrm{~mL}$ of a methanol:NaOH solution (100:2, vol/ wt) followed by $0.5 \mathrm{~mL}$ of methanol:boron trifluoride (100:20, vol/vol) and $2 \mathrm{~mL}$ of hexane. Fatty acid methyl esters were then injected into a gas chromatograph (Varian 3400, Varian, Les Ulis, France) equipped with an electron ionization detector and an SP-2560 column (100 $\mathrm{m} \times 0.25$ i.d., $0.20-\mu \mathrm{m}$ film). The carrier gas was helium. The oven temperature program was as follows: increased to $80^{\circ} \mathrm{C}$ and held for $7 \mathrm{~min}$, increased from 80 to $155^{\circ} \mathrm{C}$ at $7^{\circ} \mathrm{C} / \mathrm{min}$ and held for $32 \mathrm{~min}$, increased from 155 to $235^{\circ} \mathrm{C}$ at $2^{\circ} \mathrm{C} / \mathrm{min}$ and held for $10 \mathrm{~min}$. The injector temperature was increased from 78 to $235^{\circ} \mathrm{C}$ at a rate of $80^{\circ} \mathrm{C} / \mathrm{min}$ and the detector temperature was $235^{\circ} \mathrm{C}$.

\section{Calculations and Statistical Analyses}

Milk performance and intakes of DM, net energy, and PDI were determined using averaged data over the last $3 \mathrm{~d}$ of each experimental week. Mammary gland nutrient extraction from the blood was presented for each nutrient as an AVD and an extraction rate ( = AVD/ arterial plasma concentration $\times 100)$. The mammary plasma flow was estimated from the MBF corrected for arterial hematocrit values. The mammary uptake of each nutrient was calculated by multiplying the mammary plasma flow by the AVD. The mammary uptake of dioxygen and mammary output of carbon dioxide were calculated by multiplying the MBF by the AVD for dioxygen and the venous-arterial difference (VAD) for carbon dioxide. The efficiency of the mammary gland to utilize glucose or acetate, and BHBA or $\alpha$-amino nitrogen for either milk lactose or short- and mediumchain fatty acids or protein synthesis, respectively); was estimated using the milk output:nutrient uptake ratio (expressed in mol of carbon/mol of carbon). Amino acid carbon uptake by the mammary gland was estimated based on the hypothesis that $\alpha$-amino nitrogen corresponds to an amino acid with 6 carbon atoms and that $3.5 \%$ of milk proteins arise from plasma (Cant et al., 1993). De novo fatty acid yield was estimated based on the hypothesis that all fatty acids from $\mathrm{C}_{4}$ to $\mathrm{C}_{14}$ and only $50 \%$ of $\mathrm{C}_{16}$ are synthesized by the mammary gland (Palmquist et al., 1969).

The data were analyzed using the MIXED procedure of SAS (SAS Institute, 1990) according to the following statistical model: 
Table 2. Effects of milking frequency and feeding level on feed intake and milk yield averaged over the last $3 \mathrm{~d}$ of treatments in dairy cows ${ }^{1}$

\begin{tabular}{|c|c|c|c|c|c|c|c|c|}
\hline \multirow[b]{2}{*}{ Item } & \multicolumn{2}{|c|}{$98 \%$} & \multicolumn{2}{|c|}{$70 \%$} & \multirow[b]{2}{*}{ SEM } & \multicolumn{3}{|c|}{ Effect $^{2}(P$-value $)$} \\
\hline & TDM & ODM & TDM & ODM & & MF & FL & $\mathrm{MF} \times \mathrm{FL}$ \\
\hline DMI, kg/d & 20.4 & 19.5 & 15.2 & 15.3 & 0.67 & 0.50 & 0.006 & 0.47 \\
\hline \multicolumn{9}{|l|}{ Net energy, Mcal/d } \\
\hline Intake & 30.4 & 29.2 & 22.8 & 22.9 & 0.99 & 0.51 & 0.006 & 0.47 \\
\hline Balance & 1.1 & 2.6 & -3.8 & -0.3 & 0.71 & 0.01 & 0.009 & 0.20 \\
\hline \multicolumn{9}{|l|}{$\mathrm{PDI},{ }^{3} \mathrm{~g} / \mathrm{d}$} \\
\hline Intake & 1,946 & 1,879 & 1,459 & 1,467 & 64.6 & 0.58 & 0.007 & 0.49 \\
\hline Balance & 143 & 353 & -75 & 125 & 57.5 & 0.008 & 0.03 & 0.92 \\
\hline Milk yield, kg/d & 26.5 & 21.0 & 23.2 & 18.6 & 0.62 & $<0.0001$ & 0.04 & 0.22 \\
\hline \multicolumn{9}{|l|}{ Milk protein } \\
\hline $\mathrm{g} / \mathrm{d}$ & 885 & 706 & 711 & 588 & 21.7 & $<0.0001$ & 0.02 & 0.03 \\
\hline$\%$ & 3.36 & 3.38 & 3.09 & 3.20 & 0.055 & 0.22 & 0.02 & 0.41 \\
\hline \multicolumn{9}{|l|}{ Milk fat } \\
\hline $\mathrm{g} / \mathrm{d}$ & 1,107 & 998 & 946 & 762 & 36.8 & 0.007 & 0.01 & 0.32 \\
\hline$\%$ & 4.20 & 4.84 & 4.07 & 4.11 & 0.192 & 0.11 & 0.09 & 0.15 \\
\hline
\end{tabular}

${ }^{1}$ Milking frequency = twice-daily milking $(\mathrm{TDM})$ or once-daily milking (ODM); feeding level: $98 \%$ and $70 \%$ of requirements determined the week before the trial.

${ }^{2}$ Effects: $\mathrm{MF}=$ milking frequency; $\mathrm{FL}=$ feeding level.

${ }^{3}$ Protein truly digested in the small intestine (Jarrige, 1989).

$$
\begin{gathered}
\mathrm{Y}_{\mathrm{ijklm}}=\mu+\operatorname{cow}_{\mathrm{i}}+\text { period }_{\mathrm{j}}+\text { feeding level }_{\mathrm{k}} \\
+\mathrm{wk}(\text { period })_{\mathrm{jl}}+\text { milking frequency }_{\mathrm{m}}+\text { feeding level }_{\mathrm{k}} \\
\times \text { milking frequency }_{\mathrm{m}}+\varepsilon_{\mathrm{ijklm}}
\end{gathered}
$$

with $\mathrm{Y}_{\mathrm{ijklm}}$ being the variable dependent on cow i receiving feeding level $\mathrm{k}$ and allocated to milking frequency $\mathrm{m}$ during period $\mathrm{j}$ and $\mathrm{wk} \mathrm{l}$, and $\varepsilon_{\mathrm{ijklm}}$ the residual error associated with each ijklm observation. This model conferred considerable accuracy on the statistical test for the milking frequency effect and limited the power of the feeding level effect due to the small number of degrees of freedom and the largest residual error used (Steel and Torrie, 1980). Results are expressed as least squares means with the highest standard error of the means. The significance threshold was set at $P \leq 0.05$ and trends were noted at $P \leq 0.10$.

\section{RESULTS}

Statistical analysis revealed no interaction between milking frequency and feeding level with respect to feed, milk, and blood parameters, except for a few parameters such as milk protein and casein yields, milk medium- and long-chain fatty acids, milk saturated fatty acids, and NEFA metabolism. For this reason, the effects of milking frequency and feeding level are described separately except for the parameters referred to above.

\section{Feeding, Milk Yield, and Milk Composition}

During the last $3 \mathrm{~d}$ of treatment, the $98 \%$ feeding level provided per day, respectively, $19.9 \mathrm{~kg}$ of DMI, 29.8 Mcal of $\mathrm{NE}_{\mathrm{L}}$, and 1,913 $\mathrm{g}$ of PDI (Table 2). The net energy and PDI balances were positive (1.86 Mcal/d and $248 \mathrm{~g} / \mathrm{d}$, respectively). The $70 \%$ feeding level treatment provided $15.3 \mathrm{~kg} / \mathrm{d}$ of DMI, $22.8 \mathrm{Mcal} / \mathrm{d}$ of net energy, and $1,463 \mathrm{~g} / \mathrm{d}$ of PDI. The net energy balance was negative $(-2.07 \mathrm{Mcal} / \mathrm{d})$ and the PDI balance was positive $(25 \mathrm{~g} / \mathrm{d})$. The experimental conditions thus reduced the intakes, per day, of DM, $\mathrm{NE}_{\mathrm{L}}$, and PDI by $4.7 \mathrm{~kg}, 7.0$ Mcal, and $450 \mathrm{~g}$.

Milk yield and milk fat yield decreased under ODM and feed restriction by 5.1 and $2.9 \mathrm{~kg} / \mathrm{d}(P<0.0001$ and $P=0.04$, respectively) and by 147 and $198 \mathrm{~g} / \mathrm{d}(P=$ 0.007 and 0.01 , respectively). The milk protein yield decreased in response to both ODM and feed restriction $(P<0.0001$ and $P=0.02$, respectively). Under ODM, a smaller reduction in milk protein yield was observed when cows were fed $70 \%$ of their requirements rather than $98 \%$ ( -123 vs. $-179 \mathrm{~g} / \mathrm{d}$, respectively; $P_{\text {interaction }}=$ 0.03). Milk protein and fat contents varied differently between treatments. The milk protein content was unchanged under ODM but decreased by 0.23 percentage units under feed restriction $(P=0.02)$. The milk fat content did not vary under ODM $(P=0.11)$ although the average was greater by $0.34 \%$ percentage units. It tended to be lower by 0.43 percentage units under feed restriction $(P=0.09)$.

Similar variations in milk yield and milk fat and protein yields and contents were observed in right-half udder milk collected on $\mathrm{d} 7$ of the experimental week, although the significance thresholds were different (Table 3). Milk casein yield decreased in response to ODM and feed restriction $(P<0.0001$ and $P=0.01$, respectively), and the reduction induced by ODM was greater for the $98 \%$ feeding level than for the $70 \%$ feeding level 
Table 3. Effects of milking frequency and feeding level on the milk yield and milk composition of the righthalf udder on $\mathrm{d} 7$ of treatments in dairy cows ${ }^{1}$

\begin{tabular}{|c|c|c|c|c|c|c|c|c|}
\hline \multirow[b]{2}{*}{ Item } & \multicolumn{2}{|c|}{$98 \%$} & \multicolumn{2}{|c|}{$70 \%$} & \multirow[b]{2}{*}{ SEM } & \multicolumn{3}{|c|}{ Effect $^{2}(P$-value $)$} \\
\hline & TDM & ODM & TDM & ODM & & MF & FL & $\mathrm{MF} \times \mathrm{FL}$ \\
\hline Milk yield, kg/d & 13.3 & 10.6 & 11.4 & 9.3 & 0.37 & 0.0001 & 0.04 & 0.27 \\
\hline \multicolumn{9}{|l|}{ Milk protein } \\
\hline $\mathrm{g} / \mathrm{d}$ & 439 & 357 & 349 & 297 & 12.3 & 0.0002 & 0.02 & 0.09 \\
\hline$\%$ & 3.33 & 3.38 & 3.07 & 3.22 & 0.036 & 0.02 & 0.008 & 0.20 \\
\hline \multicolumn{9}{|l|}{ Casein } \\
\hline $\mathrm{g} / \mathrm{d}$ & 366 & 287 & 289 & 237 & 8.84 & $<0.0001$ & 0.01 & 0.05 \\
\hline$\%$ & 2.76 & 2.72 & 2.54 & 2.58 & 0.039 & 0.96 & 0.01 & 0.31 \\
\hline \multicolumn{9}{|l|}{ Whey protein } \\
\hline $\mathrm{g} / \mathrm{d}$ & 75.1 & 74.1 & 62.2 & 63.8 & 3.78 & 0.92 & 0.06 & 0.67 \\
\hline$\%$ & 0.57 & 0.70 & 0.55 & 0.69 & 0.015 & 0.0002 & 0.30 & 0.76 \\
\hline \multicolumn{9}{|l|}{ Milk fat } \\
\hline $\mathrm{g} / \mathrm{d}$ & 533 & 484 & 456 & 378 & 33.2 & 0.05 & 0.09 & 0.58 \\
\hline$\%$ & 4.05 & 4.66 & 3.99 & 4.06 & 0.268 & 0.23 & 0.27 & 0.32 \\
\hline $\mathrm{C}_{4}$ to $\mathrm{C}_{13}, \%$ & 16.5 & 16.5 & 15.9 & 15.9 & 0.31 & 0.89 & 0.17 & 0.91 \\
\hline $\mathrm{C}_{14}$ to $\mathrm{C}_{17}, \%$ & 56.1 & 54.6 & 53.2 & 54.6 & 0.90 & 0.97 & 0.27 & 0.05 \\
\hline $\mathrm{C}_{18}$ to $\mathrm{C}_{20}, \%$ & 27.4 & 28.9 & 30.9 & 29.4 & 0.77 & 0.95 & 0.11 & 0.04 \\
\hline Odd fatty acids, $\%$ & 1.75 & 1.62 & 1.67 & 1.75 & 0.124 & 0.76 & 0.85 & 0.26 \\
\hline Saturated fatty acids, $\%$ & 75.7 & 73.6 & 71.9 & 72.8 & 0.81 & 0.46 & 0.06 & 0.09 \\
\hline \multicolumn{9}{|l|}{ Lactose } \\
\hline $\mathrm{g} / \mathrm{d}$ & 652 & 508 & 556 & 429 & 15.8 & 0.0001 & 0.01 & 0.52 \\
\hline$\%$ & 4.88 & 4.77 & 4.85 & 4.62 & 0.077 & 0.06 & 0.31 & 0.42 \\
\hline
\end{tabular}

${ }^{1}$ Milking frequency = twice-daily milking $(\mathrm{TDM})$ or once-daily milking $(\mathrm{ODM})$; feeding level: $98 \%$ and $70 \%$ of requirements determined the week before the trial.

${ }^{2}$ Effects: $\mathrm{MF}$ = milking frequency; $\mathrm{FL}=$ feeding level.

$\left(-79\right.$ vs. $-52 \mathrm{~g} / \mathrm{d}$, respectively; $\left.P_{\text {interaction }}=0.05\right)$. The milk casein content was not influenced by ODM and declined from 2.74 to $2.56 \%$ under feed restriction $(P=$ 0.01 ). The whey protein yield remained unchanged under ODM and tended to decline under feed restriction by $11.6 \mathrm{~g} / \mathrm{d}(P=0.06)$. As a result, the whey protein content increased by 0.137 percentage units under ODM $(P=0.0002)$, but did not vary under feed restriction. Only minor variations were observed in milk fatty acid composition. When cows were milked twice daily, the proportion of medium-chain fatty acids tended to decrease under feed restriction by 2.8 percentage units, whereas that of long-chain fatty acids increased by 3.5 percentage units $\left(P_{\text {interaction }}=0.05\right.$ and 0.04 , respectively). Odd fatty acids were not changed by treatments. Saturated fatty acids tended to decrease less in response to feed restriction for ODM vs. TDM cows $\left(P_{\text {inter- }}\right.$ action $=0.09)$. The lactose yield decreased under ODM and feed restriction by 136 and $87 \mathrm{~g} / \mathrm{d}(P=0.0001$ and 0.01 , respectively). The lactose content tended to decrease under ODM from 4.87 to $4.69 \%(P=0.06)$, but was not changed by feed restriction.

\section{MBF and Plasma Metabolites}

Daily MBF values averaged for d 5 to 7 were reduced by both $\mathrm{ODM}(-0.64 \mathrm{~L} / \mathrm{min})$ and feed restriction $(-0.84$
$\mathrm{L} / \mathrm{min})(P=0.007$ and 0.03 , respectively; Table 4$)$. These decreases were observed when the cows were both upright and supine, with both treatments. The MBF values decreased to a similar extent in both the upright and supine positions under feed restriction (by 0.87 and $0.83 \mathrm{~L} / \mathrm{min}, P=0.03$ and 0.07 , respectively). Under ODM, these values tended to decrease less $(P=0.08)$ when cows were in an upright position rather than supine $(-0.46$ vs. $-0.82 \mathrm{~L} / \mathrm{min} ; P=0.02$ and 0.005 , respectively). The cows spent about $65 \%$ of their time standing up and tended to spend more time in an upright position when milked once daily compared with $\operatorname{TDM}$ ( 977 vs. $910 \mathrm{~min} / \mathrm{d}, P=0.08$, respectively). Similar trends were observed on $d 7$ of the experimental week: daily MBF values fell from 5.45 to $4.71 \mathrm{~L} / \mathrm{min}$ under ODM and from 5.53 to $4.63 \mathrm{~L} / \mathrm{min}$ under feed restriction $(P=0.01$ and 0.03 , respectively).

Under ODM, the plasma arterial glucose concentration increased by $0.15 \mathrm{~m} M(P=0.01$; Table 5). Glucose AVD and extraction rate were reduced by $0.08 \mathrm{~m} M$ and $2.6 \%(P=0.02$ and 0.006 , respectively). As a result, mammary glucose uptake decreased by $0.78 \mathrm{mmol} / \mathrm{min}$ $(P=0.0009)$. Under feed restriction, the arterial concentration, AVD, and glucose extraction rates did not vary. Only the mammary glucose uptake decreased by 0.70 $\mathrm{mmol} / \mathrm{min}$ under feed restriction $(P=0.008)$.

The arterial concentration, AVD, and extraction rate of $\alpha$-amino nitrogen and acetate were not influenced by 
Table 4. Effects of milking frequency and feeding level on mammary blood flow (MBF) in the right-half udder over the last $3 \mathrm{~d}$ of treatments in dairy cows ${ }^{1}$

\begin{tabular}{|c|c|c|c|c|c|c|c|c|}
\hline \multirow[b]{2}{*}{ Item } & \multicolumn{2}{|c|}{$98 \%$} & \multicolumn{2}{|c|}{$70 \%$} & \multirow[b]{2}{*}{ SEM } & \multicolumn{3}{|c|}{ Effect $^{2}(P$-value $)$} \\
\hline & TDM & ODM & TDM & ODM & & MF & FL & $\mathrm{MF} \times \mathrm{FL}$ \\
\hline $\mathrm{MBF}, \mathrm{L} / \mathrm{min}$ & 5.76 & 5.11 & 4.91 & 4.28 & 0.203 & 0.007 & 0.03 & 0.97 \\
\hline $\mathrm{MBF}$ in an upright position, $\mathrm{L} / \mathrm{min}$ & 5.35 & 4.85 & 4.45 & 4.02 & 0.193 & 0.02 & 0.03 & 0.81 \\
\hline MBF in a supine position, $\mathrm{L} / \mathrm{min}$ & 6.47 & 5.67 & 5.67 & 4.82 & 0.256 & 0.005 & 0.07 & 0.89 \\
\hline Time in a upright position, $\%$ & 63.8 & 68.7 & 63.3 & 67.7 & 2.37 & 0.08 & 0.74 & 0.91 \\
\hline
\end{tabular}

${ }^{1}$ Milking frequency = twice-daily milking $(\mathrm{TDM})$ or once-daily milking (ODM); feeding level: $98 \%$ and $70 \%$ of requirements determined the week before the trial.

${ }^{2}$ Effects: $\mathrm{MF}$ = milking frequency; $\mathrm{FL}$ = feeding level.

any of the treatments (Table 5). The mammary uptake of $\alpha$-amino nitrogen did not vary under ODM and feed restriction, although it was lower under feed restriction by $0.57 \mathrm{mmol} / \mathrm{min}(P=0.11)$. The mammary uptake of acetate decreased by 0.92 and $1.07 \mathrm{mM}$ under ODM and feed restriction $(P=0.004$ and 0.03 , respectively).
Arterial concentrations of BHBA were not changed by any of the treatments. Under ODM, the AVD of BHBA increased and its extraction rate tended to increase $(P=0.04$ and 0.07 , respectively). Under feed restriction, the AVD of BHBA tended to decline $(P=$ 0.08 ) but the extraction rate did not vary although the

Table 5. Effects of milking frequency and feeding level on the metabolism of glucose, $\alpha$-amino nitrogen, acetate, BHBA, total glycerol and NEFA, and plasma concentrations of insulin and IGF-I in the right-half udder on $\mathrm{d} 7$ of treatments in dairy cows ${ }^{1}$

\begin{tabular}{|c|c|c|c|c|c|c|c|c|}
\hline \multirow[b]{2}{*}{ Item } & \multicolumn{2}{|c|}{$98 \%$} & \multicolumn{2}{|c|}{$70 \%$} & \multirow[b]{2}{*}{ SEM } & \multicolumn{3}{|c|}{ Effect $^{2}(P$-value $)$} \\
\hline & TDM & ODM & TDM & ODM & & MF & FL & $\mathrm{MF} \times \mathrm{FL}$ \\
\hline \multicolumn{9}{|l|}{ Glucose } \\
\hline Arterial concentration, $\mathrm{m} M$ & 4.02 & 4.21 & 3.95 & 4.05 & 0.066 & 0.01 & 0.24 & 0.28 \\
\hline $\mathrm{AVD}^{3} \mathrm{~m} M$ & 0.86 & 0.79 & 0.83 & 0.75 & 0.038 & 0.02 & 0.44 & 0.85 \\
\hline Extraction rate, $\%$ & 21.5 & 18.8 & 21.0 & 18.5 & 0.72 & 0.006 & 0.63 & 0.85 \\
\hline $\begin{array}{l}\text { Mammary uptake, } \mathrm{mmol} / \mathrm{min} \\
\alpha \text {-amino nitrogen }\end{array}$ & 3.73 & 2.92 & 3.00 & 2.25 & 0.122 & 0.0009 & 0.008 & 0.81 \\
\hline Arterial concentration, $\mathrm{m} M$ & 2.59 & 2.68 & 2.65 & 2.56 & 0.107 & 0.98 & 0.80 & 0.41 \\
\hline $\mathrm{AVD}, \mathrm{m} M$ & 0.48 & 0.51 & 0.45 & 0.43 & 0.088 & 0.89 & 0.54 & 0.79 \\
\hline Extraction rate, $\%$ & 18.5 & 18.9 & 16.5 & 17.3 & 2.97 & 0.84 & 0.55 & 0.94 \\
\hline Mammary uptake, $\mathrm{mmol} / \mathrm{min}$ & 2.17 & 1.84 & 1.55 & 1.34 & 0.281 & 0.34 & 0.11 & 0.83 \\
\hline \multicolumn{9}{|l|}{ Acetate } \\
\hline Arterial concentration, $\mathrm{m} M$ & 2.02 & 1.85 & 1.97 & 2.01 & 0.085 & 0.43 & 0.50 & 0.23 \\
\hline $\mathrm{AVD}, \mathrm{m} M$ & 1.42 & 1.31 & 1.37 & 1.37 & 0.046 & 0.21 & 0.93 & 0.22 \\
\hline Extraction rate, \% & 70.7 & 70.7 & 69.5 & 67.7 & 1.25 & 0.45 & 0.17 & 0.46 \\
\hline Mammary uptake, $\mathrm{mmol} / \mathrm{min}$ & 6.14 & 4.97 & 4.82 & 4.15 & 0.242 & 0.004 & 0.03 & 0.21 \\
\hline \multicolumn{9}{|l|}{ BHBA } \\
\hline Arterial concentration, $\mathrm{m} M$ & 0.96 & 1.00 & 0.97 & 0.96 & 0.037 & 0.67 & 0.68 & 0.55 \\
\hline $\mathrm{AVD}, \mathrm{m} M$ & 0.35 & 0.40 & 0.31 & 0.35 & 0.018 & 0.04 & 0.08 & 0.62 \\
\hline Extraction rate, \% & 36.0 & 40.4 & 31.8 & 36.3 & 2.17 & 0.07 & 0.13 & 0.97 \\
\hline Mammary uptake, $\mathrm{mmol} / \mathrm{min}$ & 1.52 & 1.52 & 1.13 & 1.05 & 0.084 & 0.63 & 0.01 & 0.58 \\
\hline \multicolumn{9}{|l|}{ Total glycerol } \\
\hline Arterial concentration, $\mu M$ & 53.2 & 65.5 & 59.9 & 63.9 & 3.78 & 0.04 & 0.56 & 0.23 \\
\hline AVD,$\mu M$ & 17.3 & 21.2 & 19.9 & 20.2 & 1.22 & 0.12 & 0.52 & 0.18 \\
\hline Extraction rate, $\%$ & 33.0 & 34.2 & 34.1 & 32.4 & 2.37 & 0.90 & 0.89 & 0.54 \\
\hline \multirow{2}{*}{\multicolumn{9}{|c|}{ NEFA }} \\
\hline & & & & & & & & \\
\hline Arterial concentration, $\mu M$ & 51.5 & 50.7 & 86.0 & 55.3 & 4.62 & 0.0002 & 0.05 & 0.0003 \\
\hline $\mathrm{AVD}, \mu M$ & -13.3 & -18.1 & 7.6 & -9.4 & 2.51 & 0.003 & 0.01 & 0.03 \\
\hline Mammary uptake, $\mu \mathrm{mol} / \mathrm{min}$ & -59.5 & -68.5 & 31.5 & -27.4 & 13.30 & 0.02 & 0.02 & 0.05 \\
\hline Insulin concentration, $\mathrm{mg} / \mathrm{L}$ & 1.88 & 1.77 & 1.55 & 1.65 & 0.188 & 0.98 & 0.30 & 0.54 \\
\hline IGF-I concentration, $\mathrm{mg} / \mathrm{L}$ & 157 & 182 & 137 & 162 & 7.4 & 0.005 & 0.10 & 0.98 \\
\hline
\end{tabular}

${ }^{1}$ Milking frequency = twice-daily milking (TDM) or once-daily milking (ODM); feeding level: $98 \%$ and $70 \%$ of requirements determined the week before the trial.

${ }^{2}$ Effects: $\mathrm{MF}$ = milking frequency; $\mathrm{FL}$ = feeding level.

${ }^{3}$ Arterio-venous difference. 
Table 6. Effects of milking frequency and feeding level on the metabolism of dioxygen and carbon dioxide in the right-half udder on $\mathrm{d} 7$ of treatments in dairy cows ${ }^{1}$

\begin{tabular}{|c|c|c|c|c|c|c|c|c|}
\hline \multirow[b]{2}{*}{ Item } & \multicolumn{2}{|c|}{$98 \%$} & \multicolumn{2}{|c|}{$70 \%$} & \multirow[b]{2}{*}{ SEM } & \multicolumn{3}{|c|}{$\operatorname{Effect}^{2}(P$-value $)$} \\
\hline & TDM & ODM & TDM & ODM & & MF & FL & $\mathrm{MF} \times \mathrm{FL}$ \\
\hline \multicolumn{9}{|l|}{ Dioxygen } \\
\hline Arterial concentration, $\mathrm{m} M$ & 5.6 & 5.6 & 5.8 & 6.0 & 0.17 & 0.33 & 0.21 & 0.24 \\
\hline $\mathrm{AVD},{ }^{3} \mathrm{~m} M$ & 1.5 & 1.5 & 1.5 & 1.6 & 0.08 & 0.52 & 0.99 & 0.70 \\
\hline Extraction rate, \% & 26.9 & 27.3 & 25.3 & 25.6 & 0.80 & 0.65 & 0.11 & 0.92 \\
\hline Mammary uptake, $\mathrm{mmol} / \mathrm{min}$ & 9.0 & 7.8 & 7.4 & 6.7 & 0.24 & 0.009 & 0.009 & 0.26 \\
\hline \multicolumn{9}{|l|}{ Carbon dioxide } \\
\hline Arterial concentration, $\mathrm{m} M$ & 27.2 & 27.4 & 26.1 & 25.8 & 0.52 & 0.85 & 0.08 & 0.59 \\
\hline $\mathrm{VAD},{ }^{4} \mathrm{~m} M$ & 2.1 & 2.2 & 1.8 & 2.0 & 0.20 & 0.55 & 0.37 & 0.61 \\
\hline Mammary output, $\mathrm{mmol} / \mathrm{min}$ & 13.0 & 11.2 & 9.3 & 8.8 & 0.55 & 0.03 & 0.02 & 0.11 \\
\hline Respiratory quotient & 1.42 & 1.41 & 1.22 & 1.26 & 0.101 & 0.87 & 0.17 & 0.78 \\
\hline
\end{tabular}

${ }^{1}$ Milking frequency = twice-daily milking (TDM) or once-daily milking (ODM); feeding level: $98 \%$ and $70 \%$ of requirements determined the week before the trial.

${ }^{2}$ Effects: MF = milking frequency; FL = feeding level.

${ }^{3}$ Arterio-venous difference.

${ }^{4}$ Venous-arterial difference.

average was lower $(P=0.13)$. As a result, the mammary uptake of BHBA did not vary under ODM and was reduced under feed restriction by $0.43 \mathrm{mM}(P=0.01)$.

The arterial concentration of total glycerol increased by $14.5 \%$ under ODM $(P=0.04)$ and was unaffected by feed restriction. The AVD of total glycerol did not vary under any of the treatments although it appeared to be $11.3 \%$ greater under ODM $(P=0.12)$. The extraction rate was not altered by any of the treatments. The mammary uptake of total glycerol remained unchanged under both ODM and feed restriction, although the average was smaller under feed restriction by $11.5 \mu \mathrm{mol} /$ $\min (P=0.12)$.

The arterial concentration of NEFA increased in response to feed restriction but more slowly for ODM vs. TDM cows ( +4.6 vs. $+34.5 \mu M$, respectively; $P_{\text {interaction }}=$ $0.0003)$. At a $98 \%$ feeding level, NEFA AVD and mammary uptake were negative, averaging $-13.3 \mu M$ and $-59.5 \mu \mathrm{mol} / \mathrm{min}$, and were not affected by ODM. At a $70 \%$ feeding level, the NEFA AVD and mammary uptake became positive with TDM and decreased to become negative under ODM $\left(P_{\text {interaction }}=0.03\right.$ and 0.05 , respectively).

Plasma insulin concentrations remained unchanged under both treatments. In response to ODM, plasma IGF-I concentrations increased by $25.3 \mathrm{mg} / \mathrm{L}(P=$ $0.005)$. In contrast, IGF-I concentrations tended to decrease by $19.6 \mathrm{mg} / \mathrm{L}$ in response to feed restriction $(P=0.10)$.

\section{Blood Gases}

The arterial concentration, AVD, and extraction rate of dioxygen remained unchanged under ODM and feed restriction (Table 6). Only mammary dioxygen uptake decreased under ODM and feed restriction (by -0.9 and $-1.4 \mathrm{mmol} / \mathrm{min}, P=0.009$ and 0.009 , respectively). Arterial carbon dioxide concentrations were unchanged under ODM and tended to decline with feed restriction by $1.4 \mathrm{mM}(P=0.08)$. Carbon dioxide VAD was not affected by the different treatments. Mammary carbon dioxide output decreased with ODM and feed restriction by 1.1 and $3.0 \mathrm{mmol} / \mathrm{min}(P=0.03$ and 0.02 , respectively). The respiratory quotient did not vary under any of the treatments.

\section{Ratios}

The lactose output:glucose uptake ratio remained unchanged under ODM and tended to increase by $6.2 \%$ under feed restriction $(P=0.10$; Table 7$)$. The amino acid output: $\alpha$-amino nitrogen uptake and $\left(\mathrm{C}_{4}\right.$ to $\left.\mathrm{C}_{16}\right)$ output:(acetate + BHBA) uptake ratios were not influenced by any of the treatments.

\section{DISCUSSION}

The different treatments generated distinct nutritional states, characterized by more- or less-pronounced positive or negative energy balances. Cows receiving $70 \%$ of their requirements and milked twice daily compensated for their $6.6 \mathrm{Mcal}$ of $\mathrm{NE}_{\mathrm{L}}$ energy deficit by reducing FCM from 27.1 to $23.5 \mathrm{~kg} / \mathrm{d}$; that is, an economy of $2.7 \mathrm{Mcal}$ of $\mathrm{NE}_{\mathrm{L}}$ per d (Jarrige, 1989) and by mobilizing body reserves to a level of 3.8 Mcal of $\mathrm{NE}_{\mathrm{L}} / \mathrm{d}$. Feed-restricted cows milked once daily compensated for their $3.6 \mathrm{Mcal}$ of $\mathrm{NE}_{\mathrm{I}} / \mathrm{d}$ energy deficit by reducing FCM from 23.4 to $18.8 \mathrm{~kg} / \mathrm{d}$ (i.e., $3.4 \mathrm{Mcal} / \mathrm{d}$ ) without mobilizing body reserves. Milk fatty acid profile and plasma NEFA concentrations confirmed that there was 
Table 7. Effects of milking frequency and feeding level on mammary efficiency to convert nutrients into milk components on $\mathrm{d} 7$ of treatments in the right-half udder in dairy cows (in mol of carbon $/ \mathrm{mol}$ of carbon) ${ }^{1}$

\begin{tabular}{|c|c|c|c|c|c|c|c|c|}
\hline \multirow[b]{2}{*}{ Item } & \multicolumn{2}{|c|}{$98 \%$} & \multicolumn{2}{|c|}{$70 \%$} & \multirow[b]{2}{*}{ SEM } & \multicolumn{3}{|c|}{$\operatorname{Effect}^{2}(P$-value $)$} \\
\hline & TDM & ODM & TDM & ODM & & MF & FL & $\mathrm{MF} \times \mathrm{FL}$ \\
\hline Lactose output:glucose uptake & 73.7 & 72.2 & 79.3 & 79.0 & 2.90 & 0.75 & 0.10 & 0.84 \\
\hline AA output: $\alpha$-amino $\mathrm{N}$ uptake ${ }^{3}$ & 110 & 86 & 107 & 110 & 15.4 & 0.50 & 0.50 & 0.38 \\
\hline$\left(\mathrm{C}_{4}\right.$ to $\left.\mathrm{C}_{16}\right)$ output:(acetate + BHBA $)$ uptake $^{4}$ & 60.1 & 63.6 & 63.1 & 62.3 & 4.20 & 0.73 & 0.84 & 0.60 \\
\hline
\end{tabular}

${ }^{1}$ Milking frequency = twice-daily milking $(\mathrm{TDM})$ or once-daily milking (ODM); feeding level: $98 \%$ and $70 \%$ of requirements determined the week before the trial.

${ }^{2}$ Effects: $\mathrm{MF}$ = milking frequency; $\mathrm{FL}$ = feeding level.

${ }^{3}$ Quantity of AA carbon uptake by mammary gland was estimated based on the hypothesis that $\alpha$-amino nitrogen corresponds to an AA with 6 carbon atoms.

${ }^{4}$ De novo synthesis of fatty acid was estimated based on the hypothesis that all fatty acids from $\mathrm{C}_{4}$ to $\mathrm{C}_{14}$ were synthesized by the mammary gland and only $50 \%$ of $\mathrm{C}_{16}$ (Palmquist et al., 1969).

no lipid mobilization in feed-restricted cows milked once daily. Results also suggested that lipid mobilization remained moderate in feed-restricted cows milked twice daily. Indeed, in the latter, a slight elevation of plasma NEFA concentrations (by $34.5 \mu M$ ) and in the percentage of long-chain fatty acids in the milk $(+3.5$ percentage units) was observed when compared with cows receiving 98\% of their requirements. Similarly, feed restriction did not change plasma concentrations of glucose, acetate, and BHBA, in line with a pronounced dietary deficit. These results were also corroborated by plasma insulin values that did not vary under feed restriction, even though they were slightly lower compared with the $98 \%$ feeding level treatment. Variations in plasma IGF-I concentrations seemed to be linked to the energy balance of animals, as has been noted by other authors (Spicer et al., 1990; Reist et al., 2002). Plasma IGF-I concentrations were not related to variations in the milk yield of cows and the MBF.

\section{Mammary Use of Glucose and Milk Yield}

In the present study, the mammary extraction rate and uptake of glucose, and the percentage of glucose taken up and converted into lactose are in agreement with the values reported in the literature. The mammary extraction rate of glucose ranges from 18.5 to 21.5\% as noted by Davis and Collier (1985). The mammary uptake of glucose ranged from 2.25 to $3.73 \mathrm{mmol} /$ min, consistent with values reported in cows with similar yields (Guinard et al., 1994; Rigout et al., 2002). In the same way, the percentage of glucose taken up and converted into lactose was approximately $76 \%$, in line with values reported elsewhere in the literature (60 to $70 \%$ according to Faulkner and Peaker, 1987).

In the present study, the decrease in milk yield was more important under ODM than under $30 \%$ feed restriction (5.1 vs. $2.9 \mathrm{~kg} / \mathrm{d}$, respectively). This underlies variations in mammary glucose utilization, which could help in understanding how the milk volume of dairy cows is regulated. The reduction in yield resulted in a decrease in lactose production that was $136 \mathrm{~g} / \mathrm{d}$ under ODM vs. $87 \mathrm{~g} / \mathrm{d}$ under feed restriction. The more important decrease in lactose production observed under ODM could not be explained by a greater reduction in arterial glucose flow reaching the udder. Indeed, arterial glucose flow was reduced by ODM and feed restriction, but this reduction was less marked under ODM than under feed restriction $(-1.71$ vs. $-3.32 \mathrm{mmol} / \mathrm{min}$ and $P=0.047$ and 0.023 , respectively). Mammary plasma flow diminished to a similar extent under both treatments by about $0.6 \mathrm{~L} / \mathrm{min}$, but arterial glucose concentrations increased in response to ODM.

The more important drop in lactose production observed under ODM could not be explained by a greater reduction in mammary glucose uptake. Indeed, although glucose uptake diminished in response to the treatments, the reduction was similar under both ODM and feed restriction (at approximately 0.7 to $0.8 \mathrm{mmol} /$ $\mathrm{min}$ ). Whereas arterial glucose flow decreased less under ODM, mammary glucose extraction efficiency fell by $2.6 \%$ under ODM but did not vary under feed restriction. This explains why the reduction in glucose uptake was of the same order under the 2 treatments. This reduction in the glucose extraction rate in response to a switch to ODM resulted both from a decrease in the glucose AVD and an increase in the arterial glucose concentration. This result is consistent with those previously observed (Fleet and Peaker, 1978; Delamaire and Guinard-Flament, 2006b). It suggests that glucose extraction may be markedly inhibited under ODM in contrast to feed restriction.

In fact, the less-marked reduction in lactose production observed under feed restriction could be explained by an improvement in mammary ability to produce lactose from glucose. Indeed, the lactose output:glucose uptake ratio did not vary under ODM, and tended to increase by $6 \%$ under feed restriction. This preferential 
utilization of glucose for lactose synthesis in response to feed restriction was consistent with the average value of the respiratory quotient, which was lower by $13 \%$ $(P=0.17)$. This suggests a relative change in the nature of oxidative substrates in the mammary gland; the respiratory quotient is 1 when the oxidative substrate is glucose and is 0.7 to 0.8 with lipids or proteins. In the present study, the increase in glucose utilization for lactose production may have been associated with a reduction in its oxidation, thus explaining the reduction in the respiratory quotient. This hypothesis is consistent with results obtained in goats subjected to fasting for $24 \mathrm{~h}$, in which the respiratory quotient and oxidized glucose levels were also reduced (Linzell, 1974).

Thus, results on mammary glucose utilization suggested distinct mechanisms to regulate milk volume under ODM and feed restriction. This could result from the type of negative feedback exerted on milk production by these treatments. Under ODM, the mammary gland would react to an accumulation of milk in the udder by blocking the uptake of the principal precursor for lactose synthesis. Under feed restriction, the mammary gland would endure the new distribution of glucose in the body without seeking to compensate for this phenomenon by increasing the mammary extraction rate, but by redirecting the glucose taken up toward lactose synthesis.

\section{Mammary Use of Nutrients and Milk Composition}

The decrease in milk yield was accompanied by reductions in milk fat and protein yields, which differed between the treatments. Under ODM, the reductions in milk and protein yields were similar and more important than the reduction in milk fat yield $(-21,-19$ vs. $-14 \%$, respectively). The milk fat content increased slightly (+0.34 percentage units). This result has classically been observed during studies in which ODM is applied for short periods and to cows at comparable lactation stages and with similar milk yields (Davis et al., 1999; Rémond and Pomiès, 2005). Once-daily milking also resulted in a modification to the composition of proteins. Contents of soluble proteins increased by 0.14 percentage units, probably because of the influx of serum proteins into the milk linked to the opening of tight junctions (Stelwagen et al., 1994). Under feed restriction, the milk yield diminished less than the milk protein and fat yields ( -12 vs. -18 and $-19 \%$, respectively), resulting in a reduction in protein and milk fat contents of 0.23 and 0.43 percentage units, respectively. The drop in protein content, which is classically observed during reductions in energy supply (Coulon and Rémond, 1991), was linked to a 0.21-percentage-unit decrease in the milk casein content.
These variations in milk composition in response to ODM and feed restriction highlight dissimilar controls of mammary nutrient use. They could originate from the quantity of nutrient taken up by the udder and the mammary metabolic activity. Under ODM, the lessmarked reduction in milk fat yield could be explained by a smaller drop in the uptake of fat precursors. Indeed, mammary nutrient uptake diminished differently between nutrients, although their efficiency of conversion into milk components was not changed. The mammary uptake of BHBA, total glycerol, and $\alpha$-amino nitrogen did not vary, and was only diminished for glucose and acetate by 23 and $16 \%$, respectively. Similar results have been reported and discussed by Delamaire and Guinard-Flament (2006b). In the present study, mammary BHBA extraction increased by $13 \%$ in response to ODM, whereas BHBA arterial concentration did not vary. These results are consistent with the hypothesis of a weaker inhibition of milk fat synthesis and secretion than for lactose and protein under the effect of ODM.

Under feed restriction, the mammary uptake of nutrients diminished to almost the same extent for all nutrients. Uptake was reduced by $21 \%$ for glucose, by 19 , 28 , and $15 \%$ for acetate, BHBA, and total glycerol, respectively, and by $28 \%$ for $\alpha$-amino nitrogen. As a result, the decreases in milk fat and protein contents in response to this treatment did not seem to be due to a reduction of the uptake of a specific nutrient that would become limiting for milk protein or fat synthesis. In fact, these declines are due to a dilution effect that originates from lactose synthesis. Indeed, the milk component conversion efficiency of acetate, BHBA, and $\alpha$ amino nitrogen did not vary in response to feed restriction, whereas the conversion of glucose into lactose increased. This latter enhancement partly compensated the reduction in glucose uptake and led to a dilution of fat and protein into milk.

\section{Additivity of Responses}

In agreement with results reported by Lacy-Hulbert et al. (1999) and Rémond et al. (2002, 2005) in feedrestricted cows milked once or twice daily, no interactions were observed between milking frequency and feeding levels with respect to milk yield in the present study. The improvement in the $\mathrm{NE}_{\mathrm{L}}$ balance between 70 and $98 \%$ feed-restricted cows milked once daily resulted in an increase in milk yield that did not differ from that observed in cows milked twice-daily ( $+0.8 \mathrm{vs.}$ $+1.5 \mathrm{~kg}$ of $\mathrm{FCM} / \mathrm{Mcal}$ of $\mathrm{NE}_{\mathrm{L}}$, respectively).

In addition, no interactions were observed for the majority of physiological parameters (MBF, extraction, uptake:output ratio), with the exception of NEFA. This 
result suggests the independence of the regulatory mechanisms induced by ODM and feed restriction. In response to treatments, homeorhetic and homeostatic adjustments altering the mammary use of circulating nutrients occurred. These adjustments could result from different and independent mechanistic pathways with respect to ODM and feed restriction, particularly for $\mathrm{MBF}$. In the present study, MBF fell by $14 \%$ under $\mathrm{ODM}$ and feed restriction. This reduction was comparable to the results previously obtained, when the MBF fell by 10 to $16 \%$ in response to a switch from TDM to ODM (Guinard-Flament and Rulquin, 2001; Delamaire and Guinard-Flament, 2006a) or in response to a $30 \%$ restriction on ad libitum feeding (Lough et al., 1990). Instead of ODM, feed restriction may regulate MBF systemically through a modification to cardiac output and the distribution of blood in the body. According to Davis and Collier (1985), cardiac output may be reduced by about $23 \%$ in cows subjected to fasting, and the proportion of blood allocated to the mammary gland reduced by 16 to $19 \%$. This result should be linked to the variation in heart rate observed during changes in the energy balance of cows (Brosh et al., 2002). As for ODM, it may cause a drop in MBF through local regulatory mechanisms related to the mammary metabolic activity and the physical effect exerted by an accumulation of milk in the udder. Heart rate does not vary under ODM (Delamaire and Guinard-Flament, 2006a). According to these authors, the physical effect of milk accumulating in the mammary alveoli may compress the blood capillaries, thus preventing blood circulation in these vessels. This effect may explain the more important reduction in the MBF observed during the present study when the cow was supine compared with when it was standing ( -0.9 vs. $-0.6 \mathrm{~L} / \mathrm{min})$.

However, the hypothesis of a regulation via identical mechanistic pathways cannot be rejected. The control of mammary extraction and use of nutrients is complex and multifactorial. It is influenced by the number of capillaries recruited, the blood flow rate and plasma concentration of nutrients in capillaries, the model of transmembrane nutrient transport (active vs. passive), and the number and activities of enzymes involved in the different synthetic and oxidative pathways of mammary epithelial cells. Further studies should be carried out to determine the implication of these mammary factors to better understand the additive effects of ODM and feed restriction on milk yield.

\section{CONCLUSIONS}

The additive effects of ODM and feed restriction on milk yield might be explained by a relative independence of the different regulatory pathways governing the uptake and utilization of nutrients by the mammary gland. The decrease in milk and lactose yields observed in response to ODM or feed restriction was associated with a reduction in the mammary uptake of glucose partly because of depressed MBF. Under ODM, this occurred without any apparent change to the distribution of the glucose taken up between the different intramammary metabolic pathways. In contrast, under feed restriction, the mammary gland tended to mostly convert the glucose it had taken up into lactose. These adaptations in the mammary use of glucose in response to both treatments have to be confirmed but show the importance of understanding glucose utilization to explain and predict milk yield variations.

\section{ACKNOWLEDGMENTS}

The authors gratefully thank Y. Lebreton for assistance with surgical procedures; Y. David, D. Chevrel, and the Méjusseaume team for their assistance with the care and feeding of cows; and M. Texier, I. Jicquel, A. Brasseur, S. Marion, L. Finot, S. Letort-Wiart, N. Huchet, M. Vérité, and T. Le Mouel for technical assistance. We are very grateful to Mario Leonard and Helen Lapierre (Agriculture and Agri-Food Canada, Lennoxville, Canada) for IGF-I analyses. Rabbit anti-hIGF-1, lot\# AFP4892898, was obtained from the National Hormone and Peptide Program (NHPP), National Institute of Diabetes and Digestive and Kidney Diseases, Bethesda, MD, and A. F. Parlow. We gratefully acknowledge NIDDK, National Institute of Child Health and Human Development, and the USDA as well as the University of Maryland School of Medicine. The authors thank V. Hawken for help with the English translation and A. Pinhouët for assistance with bibliography.

\section{REFERENCES}

Abribat, T., H. Lapierre, P. Dubreuil, G. Pelletier, P. Gaudreau, P. Brazeau, and D. Petitclerc. 1990. Insulin-like growth factor-I concentration in Holstein female cattle: variations with age, stage of lactation and growth hormone-releasing factor administration. Domest. Anim. Endocrinol. 7:93-102.

Bauchard, D., and F. Duboisset. 1983. Utilisation des colonnes capillaires de verre pour l'analyse des acides gras du lait. Cah. Tech. Inst. Natl. Rech. Agron. Bull. Liaison Int. 1:1-53.

Brosh, A., Y. Aharoni, and Z. Holzer. 2002. Energy expenditure estimation from heart rate: validation by long-term energy balance measurement in cows. Livest. Prod. Sci. 77:287-299.

Cant, J. P., E. J. DePeters, and R. L. Baldwin. 1993. Mammary amino acid utilization in dairy cows fed fat and its relationship to milk protein depression. J. Dairy Sci. 76:762-774.

Coulon, J. B., and B. Rémond. 1991. Variations in milk output and milk protein content in response to the level of energy supply to the dairy cow: A review. Livest. Prod. Sci. 29:31-47.

Couvreur, S., C. Hurtaud, P. G. Marnet, P. Faverdin, and J. L. Peyraud. 2007. Composition of milk fat from cows selected for milk fat globule size and offered either fresh pasture or a corn silagebased diet. J. Dairy Sci. 90:392-403. 
Davis, S. R., and R. J. Collier. 1985. Mammary blood flow and regulation of substrate supply for milk synthesis. J. Dairy Sci. 68:1041-1058.

Davis, S. R., V. C. Farr, and K. Stelwagen. 1999. Regulation of yield loss and milk composition during once-daily milking: A review. Livest. Prod. Sci. 59:77-94.

Delamaire, E., and J. Guinard-Flament. 2006a. Increasing milking intervals decreases the mammary blood flow and mammary uptake of nutrients in dairy cows. J. Dairy Sci. 89:3439-3446.

Delamaire, E., and J. Guinard-Flament. 2006b. Longer milking intervals alter mammary epithelial permeability and the udder's ability to extract nutrients. J. Dairy Sci. 89:2007-2016.

Faulkner, A., and M. Peaker. 1987. Regulation of mammary glucose metabolism in lactation. Pages 535-562 in The Mammary Gland: Development, Regulation and Function. M. C. Neville and C. W. Daniel, ed. Plenum Press, New York, NY.

Fleet, I. R., and M. Peaker. 1978. Mammary function and its control at the cessation of lactation in the goat. J. Physiol. 279:491-507.

Friggens, N. C., G. C. Emmans, I. Kyriazakis, J. D. Oldham, and M. Lewis. 1998. Feed intake relative to stage of lactation for dairy cows consuming total mixed diets with a high or low ratio of concentrate to forage. J. Dairy Sci. 81:2228-2239.

Guinard, J., H. Rulquin, and R. Verite. 1994. Effect of graded levels of duodenal infusions of casein on mammary uptake in lactating cows. 1. Major nutrients. J. Dairy Sci. 77:2221-2231.

Guinard-Flament, J., and H. Rulquin. 2001. Effect of once vs. twice daily milking on mammary blood flow (MBF) in dairy cows. Livest. Prod. Sci. 70:180. (Abstr.)

Jarrige, R. 1989. Ruminant nutrition: Recommended allowances and feed tables. Institut National de la Recherche Agronomique, ed. J. Libbey, Eurotext, London, UK.

Johnson, C. L. 1984. The effect of feeding in early lactation on feed intake, yields of milk, fat and protein and on live-weight change over one lactation cycle in dairy cows. J. Agric. Sci. (Camb.) 103:629-637.

Lacy-Hulbert, S. J., M. W. Woolford, G. D. Nicholas, C. G. Prosser, and K. Stelwagen. 1999. Effect of milking frequency and pasture intake on milk yield and composition of late lactation cows. J. Dairy Sci. 82:1232-1239.

Lemosquet, S., N. Rideau, H. Rulquin, P. Faverdin, J. Simon, and R. Verite. 1997. Effects of a duodenal glucose infusion on the relationship between plasma concentrations of glucose and insulin in dairy cows. J. Dairy Sci. 80:2854-2865.

Linzell, J. L. 1974. Mammary blood flow and methods of identifying and measuring precursors of milk. Pages 143-225 in Lactation:
A comprehensive treatise. Vol 1. B. L. Larson and V. R. Smith, ed. Academic Press, London, UK.

Lough, D. S., D. L. Beede, and C. J. Wilcox. 1990. Effects of feed intake and thermal stress on mammary blood flow and other physiological measurements in lactating dairy cows. J. Dairy Sci. 73:325-332.

Palmquist, D. L., C. L. Davis, R. E. Brown, and D. S. Sachan. 1969 Avaiblability and metabolism of various substrates in ruminants. V. Entry rate into the body and incorporation into milk fat of $\mathrm{D}(-)$ -hydroxybutyrate. J. Dairy Sci. 52:633-638.

Reist, M., D. Erdin, D. von Euw, K. Tschuemperlin, H. Leuenberger, Y. Chilliard, H. M. Hammon, C. Morel, C. Philipona, Y. Zbinden, N. Kuenzi, and J. W. Blum. 2002. Estimation of energy balance at the individual and herd level using blood and milk traits in high-yielding dairy cows. J. Dairy Sci. 85:3314-3327.

Rémond, B., S. Aubailly, Y. Chilliard, D. Dupont, D. Pomiès, and M. Petit. 2002. Combined effects of once-daily milking and feeding level in the first three weeks of lactation on milk production and enzyme activities, and nutritional status, in Holstein cows. Anim. Res. 51:101-117.

Rémond, B., and D. Pomiès. 2005. Once-daily milking of dairy cows: a review of recent French experiments. Anim. Res. 54:427-442.

Rémond, B., D. Pomiès, and P. Pradel. 2005. Effet de la monotraite des vaches laitières sur leur production, selon le niveau de distribution d'aliments concentrés. Renc. Rech. Rumin. 12:229-232.

Rigout, S., S. Lemosquet, J. E. van Eys, J. W. Blum, and H. Rulquin. 2002. Duodenal glucose increases glucose fluxes and lactose synthesis in grass silage-fed dairy cows. J. Dairy Sci. 85:595-606.

SAS Institute. 1990. SAS/STAT User's Guide: Statistics. Version 6, ed 4. SAS Institute Inc., Cary, NC.

Spicer, L. J., W. B. Tucker, and G. D. Adams. 1990. Insulin-like growth factor-I in dairy cows: Relationships among energy balance, body condition, ovarian activity, and estrous behavior. J. Dairy Sci. 73:929-937.

Steel, R. G. D., and J. H. Torrie. 1980. Principles and procedures of statistics: A biometrical approach. 2nd ed. McGraw-Hill Book Co., New York, NY.

Stelwagen, K., S. R. Davis, V. C. Farr, S. J. Eichler, and I. Politis. 1994. Effect of once daily milking and concurrent somatotropin on mammary tight junction permeability and yield of cows. J. Dairy Sci. 77:2994-3001.

Vicini, J. L., W. S. Cohick, and J. H. Clark. 1988. Effects of feed intake and sodium bicarbonate on milk production and concentrations of hormones and metabolites in plasma of cows. J. Dairy Sci. 71:1232-1238. 